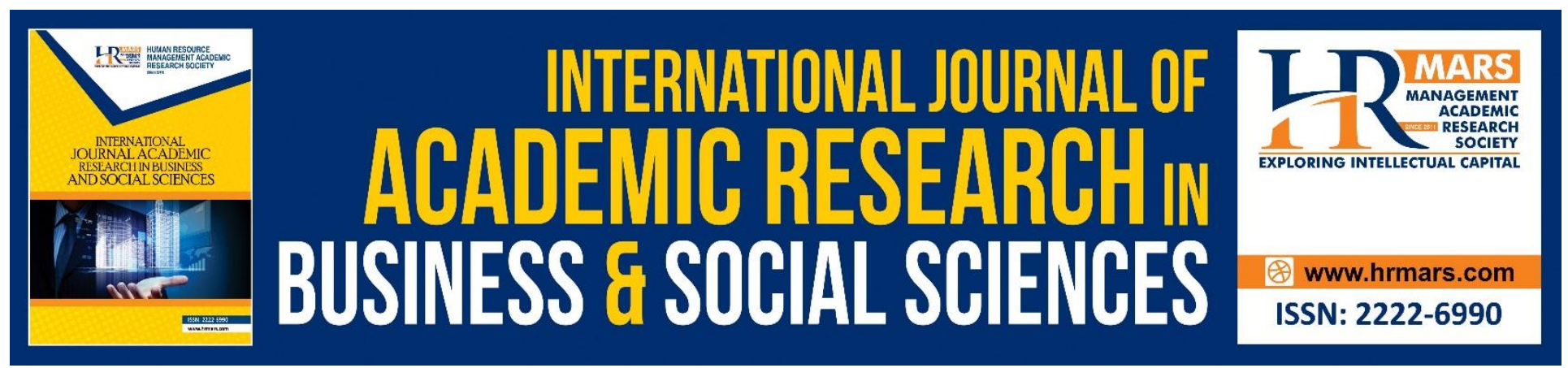

\title{
The Validity and Reliability of Well-Being Questionnaire (WBQ) for Measuring Behavioral Changes of Low-Performing Civil Servants in Malaysia
}

\section{Hazaila Hassan, Abu Yazid Abu Bakar \& Salleh Amat}

To Link this Article: http://dx.doi.org/10.6007/IJARBSS/v9-i3/5729

DOI: $\quad 10.6007 /$ IJARBSS/v9-i3/5729

Received: 13 Feb 2019, Revised: 21 March 2019, Accepted: 29 March 2019

Published Online: 03 April 2019

In-Text Citation: (Hassan, Bakar, \& Amat, 2019)

To Cite this Article: Hassan, H., Bakar, A. Y. A., \& Amat, S. (2019). The Validity and Reliability of Well-Being Questionnaire (WBQ) for Measuring Behavioral Changes of Low-Performing Civil Servants in Malaysia. International Journal of Academic Research in Business and Social Sciences, 9(3), 599-608.

\section{Copyright: (C) 2019 The Author(s)}

Published by Human Resource Management Academic Research Society (www.hrmars.com)

This article is published under the Creative Commons Attribution (CC BY 4.0) license. Anyone may reproduce, distribute, translate and create derivative works of this article (for both commercial and non-commercial purposes), subject to full attribution to the original publication and authors. The full terms of this license may be seen at: http://creativecommons.org/licences/by/4.0/legalcode

Vol. 9, No. 3, 2019, Pg. 599 - 608

Full Terms \& Conditions of access and use can be found at http://hrmars.com/index.php/pages/detail/publication-ethics 


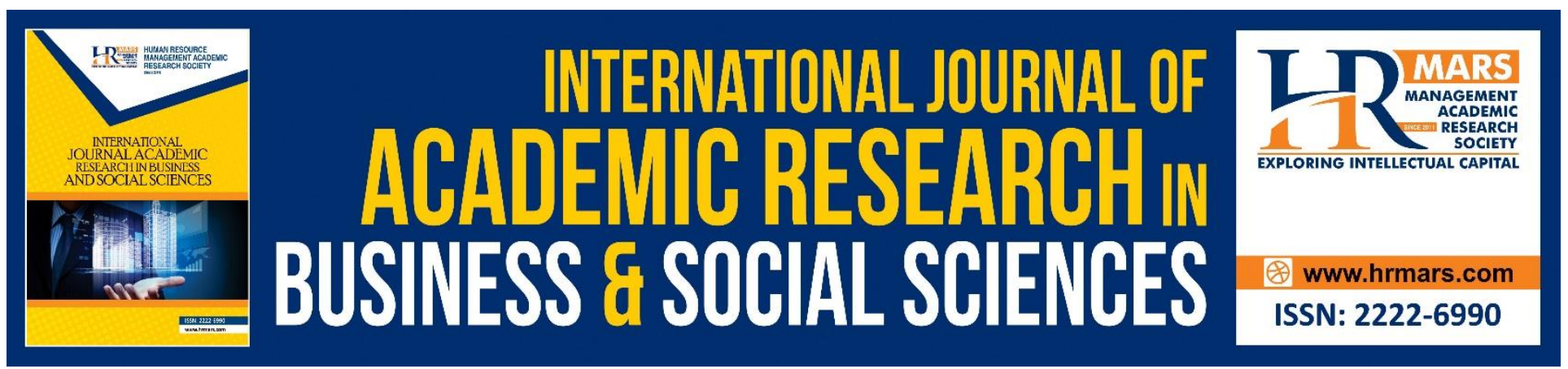

\title{
The Validity and Reliability of Well-Being Questionnaire (WBQ) for Measuring Behavioural Changes of Low-Performing Civil Servants in Malaysia
}

\author{
Hazaila Hassan, Abu Yazid Abu Bakar \& Salleh Amat \\ Faculty of Education, Universiti Kebangsaan Malaysia
}

\begin{abstract}
The objective of this study is to get a validity and reliability of the Well-Being Questionnaire (WBQ), used to measure the extent of the behavioural changes among low-performing civil servants in terms of cognitive and rationality, emotional stability, adjustment and behavioral adaptation, social skills development, and spiritual psycho-level improvement. A total of 30 respondents were involved and they are civil servants who scored below 75\% in the 2017 Performance Appraisal Report, and involved in the 3-days Self-Improvement Program. Findings of this validation study reveals that the reliability of cognitive and rational subscale is 0.943 , emotional stability subscale is 0.805 , adjustment and behavioral adaptation subscale is 0.879 , social skills development subscale is 0.866 , and spiritual psycho-level improvement subscale is 0.887 . Therefore, the WBQ instrument has obtained high validity and reliability value and is relevant to be used as measurement tool to study changes in the behavior of low-performing personnel of Malaysian civil service.
\end{abstract}

Keywords: Behavioral Changes, Instrument Validity and Reliability, Low Performing Civil Servants, Organizational Psychology, Malaysia

\section{INTRODUCTION}

Counselling is a broad discipline and has special scientific and objective bases especially in psychology, sociology, psychiatry, anthropology, and philosophy. In organizational settings, counselling approach is considered indispensable, because employees need it whether in the government, private or self-employed sectors (Hamdan, 2009; Mansur, 1998). Furthermore, in this new millennium, employees at various levels from the top management, intermediate or lower levels face various problems at the workplace. Among the common problems faced by employees are stress problems, employer and employee relationships, declining work performance, low self-esteem and failure in communication (Mustaffa, 2002). Hence, these problems require the function of an 
effective organizational counselling. In other words, a form of counselling therapy needs to be implemented effectively to treat employees who are experiencing these problems.

Among the functions and needs of organizational counselling are the methods of diagnosing employees' problems, emotional support programs, guidance services, and employee motivational training. As a result, the function of the organization's counselling services in the 21st century plays a very important role in improving the quality of the employees in total (Mustaffa, 2002). In Malaysia, counselling services in the organization exist on the employer's awareness on the importance of protecting and promoting high-value human resources. Ramlah (2001) notes that managers and supervisor relationships with employees must be treated like adults, considered as partners and respect them because they are very important assets in the organization.

However, in order to determine their achievement in service, evaluations on them in terms of behavior and their contribution to the organization is through Annual Performance Appraisal Report to see their performance and will also determine whether there is a salary increases or not. In Malaysia, the assessment is viewed from the LNPT. In this regard, there are also employees who cannot give good performance and need to be given more attention by various parties including the organization itself as well as Public Service Department. From there, the circular of Separation Policy Implementation Service Circular for Low-Performing Officers 07/2015 exists. The circular aims to inform the Government's decision to introduce the Exit Policy and its implementation method for low-performing officers in the Civil Service and from the circular, PSD takes an important role in helping to monitor these officers then the Psychological Management Division has set up a Programme Guidelines, which is intended as a reference for the intervention of the officers involved. They will be called for the counselling session in the department, and they will be present in the screening tests, namely health testing, development, finance and counselling tests. Thereafter, they will attend an intervention programme that is appropriate with the acknowledgement of the Psychological Officer intervention panel based on the guidelines set by the department. Officers below $75 \%$ will be monitored for 3 months after attending the departmental programme and if there is no change in the LNPT marks for the following year, they will be included in the Psynnova Integrated Behavior Modification Technique (i-BMT) except for health cases.

However, those who have such scores are less and decreasing, the focus of this study is on looking at those with under $75 \%$ and those who are undergoing counselling sessions that have been categorized into having financial, social, discipline, absenteeism problems, etc.

\section{RESEARCH BACKGROUNDS}

The workplace counselling psychology service is a form of intervention that pays attention to the physical and mental aspects of the employee who can support productivity improvement initiatives within the organization. Workplace counselling refers to develop employee competence, to succeed in corporate life. It will be blind to expect the supervisor to be fully trained as a functioning counselor. In fact, many problems are created because supervisors fail to recognize their limitations as counselors. They sometimes investigate too deeply (Lewis \& Lewis, 1986). The early history of this service focuses on addressing interpersonal problems among individual employees. Nowadays, the evolution of this service is growing wider to become a mental and physical welfare support system 
of workers. For example, the Employee Assistant Programme (EAP) provides activities such as supervisory training or training to manage change (Carroll, 1996). In addition, the service also plays an important role in performance management systems (Husain \& Rosli, 2002). In overseas, many Employee Assissting Programmes (EAP) are being held to enhance the skills of their employees through counselling, social work, organizational development and services to help resolve family conflicts. According to Myers (1992), an increase in problematic employee in the industry will affect the productivity of an industry. The EAP programme is conducted by employers outside the organization or within the organization to address the problem of employees and provide treatment and recovery to problematic workers. This programme also provides preventative programmes as well as reducing the burden of employees.

In Malaysia, workplace counselling aims to provide support for workers' physical and mental well-being. This effort will have the effect of increasing the productivity and performance of the workforce so that as a result the company will gain more profit. A good assumption to the company is also collected because the counselling workplace can be seen as a manifestation of corporate responsibility, law, and ethics. Employees will respect the company when employees are seen as a potential asset that should be optimally developed. In practice, the concepts mentioned earlier seem to be different. A survey conducted on 26 small and medium-sized companies in Java handling various fields found that most companies have provided optimum efforts at workplace counseling (Husain \& Rosli, n.d.). In line with that, the government's aspiration to prioritize human capital development, public-sector human resource managers should implement improvements in their management by applying psychological and counselling aspects. Human capital development is a development that focuses on human beings through that approach. Its main goal is to enhance and improve the individual for future returns (Hamat \& Nordin, 2012). Hence, human factors as human capital can be enhanced to the optimum level.

Psychological and counselling approaches are the actions that need to be taken in order to develop human capital that emphasizes on the following aspects, namely development, prevention, and recovery. The recovery aspect is emphasizing on counselling psychology services application to help improve the individual's potential. Furthermore, to examine the barriers found in individuals in giving meaningful and excellent contributions. Next, it helps individuals to face problems in their work and daily life. Milliman, Czaplewski and Ferguson (2000), believe that meaningful employment is closely related to the behavior of the individual at his or her workplace. Interests and job challenges become negative and the biggest challenge is that they decide to quit or not to work. Therefore, the concept of spirituality is emphasized, and self-concept is preferred over the challenge of work which has a positive impact on employee behavior. The employee should be helped to understand the effects of his or her behavior on himself or herself, his or her colleagues, and the organization so that he or she can immediately realize the matter and act to change the negative behavior. If the employee has a work-intent that is consistent with the organization and has the potential to succeed, it can be assisted by giving him appropriate training. Every employee whether problematic or not can gain benefit from counselling psychology services if this service is carried out seriously and systematically. This service is within an organization and not restricted to only problematic employees, even those who want to get information, purpose or share the problems (Mustaffa, 2002). 
The performance of an organization depends largely on the conduct of employees in the organization. However, in view of the existing employees, they are deemed to be of high quality to make a good contribution compared to those of poor quality (Ismail, 2011). According to Shea (2002), overall levels of job satisfaction among Malaysian workers declined since 2000 after the employees reached the age of 35 to 44 years. Riggio (2003) says that the behavior of the employee itself can affect the level of job satisfaction with the organization. The existence of turnover such as absenteeism, truancy often happens. A study by Ismail (2011), found that there was a link between job satisfaction and unproductive behavior at a university in Sabah. On work conflict, a study conducted by Rusni and Aida (2015), found that work conflicts among civil servants were largely influenced by factors of work conflict over families in terms of time of work, responsibilities in carrying out work and behavior while working. 17\% of 13 out of 533 people have family and work conflicts. While $30 \%$ of the 229 respondents are experiencing family-work conflicts and require skills to handle them. We can conclude that the conflict occurred closely with the burden of job responsibilities causing public servants to be tired, disgruntled and depressed. Conflict of work behavior affects the family when productive behavior at the workplace such as problem-solving abilities, managing or administering abilities cannot be utilized in solving problems and home management. It can be argued that the conflict in the office can interfere with the worker's performance and it creates an inability to exhibit good performance.

As of 2015, a total of 557 civil servants throughout Malaysia are categorized as nonperforming officers from various aspects such as attending counselling, development, health and non-performing officers. In 2015, 179 public officers who achieved the score below 75\% of the Appraisal were listed as low-performing officers. This encourages Public Service Department to create an Exit Policy which is a separate policy that refers to action to screen officers with below target performance. As a follow-up action, they need to create a form of intervention to help them rebuild their performance either in terms of behavior and thinking has been created. In line with that, the government has outlined that all ministries and departments have prepared some psychological officers who can assist those with problems whether those who are referred or who are voluntarily present to undergo counselling psychological intervention outlined. In Service Circular 1/1999, JPA has proposed to Head of Department to set up a counselling unit and appoint counselling officers to assist in the management of human resources in the department. The Service Circular Letter No. 4/1998 has also been issued by PSD to provide guidance on managing problematic and low-performing staff approaches through counselling services to employees of a department. JPA has also issued a Service Circular No. 18/2005 on the Psychological Application Guide in Human Resource Management that emphasizes the use of psychological elements and counselling in human resource management from the period of commencing the employment until retirement. The counselling psychology service continues to grow as a highly relevant profession in developing human resources with the unification of counselor scheme services as the Counselling Sharing Scheme from 1 January 2007. To date, psychological and counselling services have been extensively over a period of 22 years since its introduction into the public sector from 1 January 1992. 
Counselling psychological intervention in Malaysia is indispensable. Consequently, the field of counselling psychology in the organization is increasingly adopted with the existence of psychological officers at the departmental level, and the ministry as well as in the private agency. On the other hand, the existence of this service is given the utmost importance as it is one of the ways of employee assistance programs within the organization. Cheng (2012) believes that counselling at workplace can play an important role in developing a friendly and caring organizational culture in his study of counselling at the workplace. In addition, it states that the interaction of workplace counselling is very important. Discussions can create awareness about how counselling at work can help both staff and organizational development to address workplace challenges and life problems. This study also discusses the workplace and life balance that may contribute to not only a healthy workplace but also public health (Kirk \& Brown, 2003) through their review on Employee Assistance Programme (EAP), the programme provides counselling and consultancy services that focus on the prevention and recovery of personal problems experienced by employees or their family members. EAPs are now regarded as one of the major channels for job stress management and will grow rapidly for a comprehensive wellness programme at the workplace.

However, their number has decreased, so the programme has involved officers with scores under $75 \%$ who are currently undergoing counselling sessions at their respective organizations. The modules that have been tailored according to the current situation and the same content has been carried out in severalministries. The three days and two nights programme is named the Self-Strengthening Program using the Modified Psynnova IBMT Module as a guide in conducting the programme. But since the module is implemented in the public service, it is conducted internally and there is not even one academic study is carried out. However, there are questions raised that show the gap in the counselling service to these low-performing officers in the context that the dimensions involved in the module have not been evaluated as well as the dimensions of cognitive and rationality improvement, stability emotions, adjustment and behavioral adaptation and social skill development. Since local research data on psychological interventions and counselling to low-performing officers is very limited, counselors serving in ministries and departments directly involved need to understand transparently about the use of the module to address these client issues. Nevertheless, before the Psynnova Module is conducted for low-performing officials, there is a programme that has been implemented for the same target, namely Self-Transformation Programme by using LowPerforming Officer Module for three days and two nights but the programme is not detailed as the module by Psychology Department and has been carried out in detail using the Reality Therapy Theory pioneered by William Glasser.

\section{METHODOLOGY}

\section{Research Process}

This experimental study aims to see the behavior change of an employee using the Well-Being Questionnaire (WBQ). Descriptive studies are intended to get the validity of the content of the WBQI. Therefore, this section describes the review process i.e. analysis of the validity and reliability of the items of the questionnaire. 30 respondents were involved which is has features that request from 
the researchers such as in the actual study. Mohd Najib (2005) states that the reliability (reliability) an instrument is an indication of consistency and stability which allows use of the tests at different time produce the same results or almost the same. The reliability of an instrument may be determined by using several methods, such as test-retest, split-half, interrater, Kuder Richardson and Alpha's alpha. In the research methods, Alpha's alpha is the most widely used method in the research as specified by the Hair, Anderson Tatham and Black (1998). This is because they are of the opinion that the value of Alpha's minimum must be received to show high reliability against an instrument is 0.70 .

\section{Location and Respondents}

The study is conducted at one of government ministries in Putrajaya, with sample of 30 participants from the Self-Strengthening Programme. The respondents have characteristics of receiving marks below 75\% in Annual Performance Appraisal Report and those who are undergoing counselling sessions in their organization.

\section{Instrument}

The instrument used for the respondents of this study is the Well-Being Questionnaire (WIQ) which has been verified by the experts. There were 63 items in this questionnaire divided to two sections. Section A consists of 9 demographic items, whereas Section B comprises of 63 items 5-point Likert scale divided into five constructs described in Table 1.

Table 1: Analyze Component Items by Constructs

\begin{tabular}{clllc}
\hline Devision & Items & \multicolumn{1}{c}{ Constructs } & Respondent Feedback & $\begin{array}{c}\text { Number of } \\
\text { items }\end{array}$ \\
\hline A & A1-A9 & Demographic & Multiple Choice & 9 \\
B (i) & B1-B11 & $\begin{array}{l}\text { Emotional Stability } \\
\text { Improved Psycho- }\end{array}$ & D, DA, MA,A,SA & D, DA, MA,A,SA \\
(ii) & C1-C14 & $\begin{array}{l}\text { Spiritual Level } \\
\text { Social Skills }\end{array}$ & D, DA, MA,A,SA \\
(iii) & D1-D13 & $\begin{array}{l}\text { Development } \\
\text { Cognitive and Rational }\end{array}$ & D, DA, MA,A,SA \\
(iv) & E1-E12 & $\begin{array}{l}\text { Improvement } \\
\text { Adjustment and }\end{array}$ & D, DA, MA,A,SA \\
(v) & F1-F13 & Behavioural Adaptation & & 13 \\
& & & 13 \\
\hline
\end{tabular}

Notes: Very Disagree $(D)=1$, Disagree $(D A)=2$, Medium Agree $(M A)=3$, Agree $(A)=4$ and Strongly Agree $(S A)=5$. 


\section{RESULTS}

Analysis of 30 participants showed that the value of Alpha Cronbach as overall is 0.886 . According to subscale $B(\mathrm{i}), \mathrm{B}(\mathrm{ii}), \mathrm{B}(\mathrm{iii}), \mathrm{B}(\mathrm{iv}), \mathrm{B}(\mathrm{v})$ the subscale validity of the highest cognitive and rational increase is 0.943 , followed by subscale of psycho spiritual level 0.887 , adjustment and behavioral adaptation 0.879 , followed by subscale of social skill development 0.866 , and finally subscale of stability emotional 0.805 . This means that the WBQ can be considered of having good reliability and can be holistically used to measure behavioral changes of Malaysian low-performing civil servants (details as per Table 2).

Table 2: Overall and by Constructs Alpha Cronbach's Value.

\begin{tabular}{ccc}
\hline $\begin{array}{c}\text { Scale and Subscale Dimension of Behavioural } \\
\text { Change }\end{array}$ & $\begin{array}{c}\text { Alpha Cronbach's } \\
\text { Value }\end{array}$ & Item \\
\hline Overall & .886 & 63 \\
Emotional Stability & .805 & 11 \\
Improved Psycho-Spiritual Level & .887 & 14 \\
Social Skills Development & .866 & 13 \\
Cognitive and Rational Improvement & .943 & 12 \\
Adjustment and Behavioural Adaptation & .879 & 13 \\
\hline
\end{tabular}

\section{DISCUSSION}

Results of this pilot study indicate that the Well-Being Questionnaire (WBQ) is suitable to measure the behavior change of the low performance employees. The WBQ will be used as one of the measurement to see the effectiveness of counselling psychological interventions using the Psynnova Integrated Behavior Modification Technique (I-BMT) implemented against low-performing Malaysian civil servants. Low-performance means those who have marks below $75 \%$ in Annual Performance Appraisal Report. The marks are given by their superior who has the officers and staff under his or her supervision and responsible for managing the best human resources possible. Manpower management is not only in terms of enhancing knowledge, skills, and motivation but also includes managing low-performing officers.

From the observations of the Public Service Department (PSD), the heads of departments took the easy way to solve the problem of low-performing officers by asking officers to be transferred to another department or placed them in group posts. In addition, there are situations where officials are said to be underperform or problematic but in terms of Annual Performance Appraisal Report it does not reflect the condition of the organization but some have achieved high performance and are eligible to be promoted. This condition will affect the image and productivity of the department if no action is taken to remedy the situation.

In addition to the corrective action after the occurrence of the problem, the action should include preventive measures before it takes place. This includes creating a conducive environment/working environment by organizing activities that can create a sense of cooperation and family spirit such as sports and religious activities, childcare arrangements and so on. In this 
study, researchers emphasized the behavior change towards low-performing officers who achieved below 75\% in Annual Appraisal Report scores. Increasing number of problematic employees is alarming. According to statistics released by the PSD until 2015, a total of 557 officers who have been involved in various problems and have also received a recovery process, namely the counselling programme conducted by Psychology Management Division. However, these people include having disciplinary problems, absenteeism, debt, mental illness, physical illness, and even those who are involved with social problems such as stealing, taking bribes and so on.

The implication of the study also can provide theoretically and practically to the counselling unit particularly, the psychology and counselling fields as well as the practice of counselling in the public service. In fact, it will complement the psychological officers to assess the behavior changes of low-performing officers as a whole. An addition, this study can help to see the behavior changes of an employee through the Modified Psynnova Module used in the Well-Being Programme whose respondents are comprised low-performing and problematic officers using the valid measurement tools. Based on the effectiveness of the WBQ in assessing the behavior changes of an officer and as a manual intervention on behavior change, it is appropriate to conduct experimental studies of lowperforming officers using this SIW among public service officers in Malaysia. Therefore, this study is very worth to run to get faith in the use of measurement for research wants to see changes in behavior in organizations for troubled officers and performance low. Additionally, one can also see the importance of organizational counselling services today in improving the quality of workers entirely. While Kirk and Brown (2003) have also stated that nonquality services in the public sector can be overcome if civil servants are more efficient, focused on customers, transparent, and have high accountability. All of these required criteria that are closely related to the level of public servant commitment. In order to maintain quality in service, civil servants need to be mentally and physically prepared in order to enhance their commitment in providing services for all levels of positions whether they are at the support or management level.

\section{REFERENCES}

Frankel, J.R \& Wallen, N.E. (1993). How to Design and Evaluate Research in Education. Singapore. McGraw. Inc.

Kadir, H. A. (2009). Kaunseling Di Tempat Kerja. UTM.

Jabatan Perkhidmatan Awam Malaysia, Pekeliling Perkhidmatan Awam Bilangan 7, Tahun (2015). Pelaksanaan Dasar Pemisah (Exit Policy) Bagi Pegawai Yang Berprestasi Rendah Dalam Perkhidmatan Awam.

Jaafar, M. (2000). Kelakuan Organisasi (Edisi Keempat), Leeds Publications.

Abdullah, M. (1998). Kaunseling Teori, Proses dan Kaedah (Edisi ke 2), Fajar Bakti.

Meredith, D., Gall, J. P. \& Walter, R.B. (2002). Educational Research Seventh Edition.

Mustaffa, R.A. \& M.S. (2002). Keperluan Kaunseling Dalam Organisasi Di Alaf 21.

Gay, G.P. (2012) Educational Research $10^{\text {th }}$ Edition.

Boje, R. (2001). Persepsi Terhadap Perkhidmatan Kaunseling dan Hubungannya Dengan Masalah Pekerja: 1 Tinjauan di SESCO, UNIMAS.

Parker, M.R., Szymanski, E.M., \& Patterson, J.B. (Eds.). (2004). Rehabilitation counselling: Basic and beyond. (4th Ed). Texas: Pro.ed Inc. International. 
Ahmad, R. \& Mohamed Sharif Mustaffa, (2002). Keperluan Kaunseling Dalam Organisasi Di Alaf 21. UTM.

Kirk, A. K., \& Brown, D. F. (2003). Employee Assistance Programs: A Review of the Management of Stress and Wellbeing Through Workplace Counselling and Consulting. Australian Psychologist, 38(2), $138-143$. Retrieved from 10.1080/00050060310001707137\%5Cnhttp://search.ebscohost.com

Wilson, F. R., Pan, W., \& Schumsky, D. A. (2012). Measurement and Evaluation in Counseling and Development. http://doi.org/10.1177/0748175612440286 